\title{
Information Opportunities of the Digital Economy in the Process of Forecasting the Region's Labor Resources
}

\author{
Kozlova E.I. Novak M.A.* \\ Department of Economics, Lipetsk State Technical University, Lipetsk, Russia \\ "Corresponding author. Email: ferz235@mail.ru
}

\begin{abstract}
A specific tool for assessing the labor potential of a country and its regions is the reporting and forecast balance of labor resources, developed by integrating data from various sources, which requires both ensuring the availability of obtaining and using relevant information, and a special quality of working with information. The main goal of this study is to assess the accuracy of the forecast labor balance sheets developed by the management bodies at the level of a particular region; consider the analytical possibilities of statistical information contained in the regional forecast of the labor balance (for example, the Lipetsk region). The results obtained in the study can be used to identify areas of growth and areas of decline in the development of the region's labor resources, and to improve the practice of managing socio-economic processes at the regional level.
\end{abstract}

Keywords: digital transformation of information, statistical information, regional economy, labor resources,

balance of labor resources

\section{INTRODUCTION}

According to the decisions of the Rio de Janeiro UN conference on environment and development (1992) "agenda" for the twenty-first century was the concept of sustainable development, the General thrust of which is to harmonize meet the needs of present and future generations in terms of global economic growth [1]. A new level of technology plays an undeniable role in achieving this harmonization [2]. Currently, an important part of technological processes is digitalization (digital transformation of information), which allows you to use a huge amount of data processed in order to extract useful information from them.

In the digital economy, as noted by V. G. Khalin and G. $\mathrm{V}$. Chernova, it is not just processing large amounts of data in digital form, but also provides access to it for a wide range of users [3, p. 57]. The level of coverage of digital transformation of information in different sectors of the economy and different subjects (primarily citizens) is expressed in the DESI (Digital skills) Index , one of the five aggregated parameters used by EU countries to assess the results of digitalization of their national economies [4].

Big data and its processing methods are of particular importance for public administration [5, p. 31]. At the same time, the researchers note that there are some problems in forming official statistics in Russia today. For example, Yu. a. Kosova draws attention to the lack of a

high-quality level of systematization and analysis of the information of the social insurance Fund of the Russian Federation on enterprises operating in the digital economy, and the closeness of this information to external users. In her opinion, the lack of up-to-date data on enterprises engaged in this sphere of economic activity hinders both the solution of current problems in the field of eCommerce and the development of scientific forecasts $[6$, p.152]. Similar problems occur in the field of statistical and forecast developments related to the dynamics of the population, labor resources of the country, employment and the labor market, which, in particular, expressed their point of view of the participants of the annual scientific conference "Lomonosov readings-2018. Section of economic Sciences. Digital economy: people, technologies, institutions", held at the faculty of Economics of Moscow State University on April 16-23, 2018.

In our opinion, there are two main sections of information problems related to official statistics on labor resources and the labor market.

First, there is a lack of data itself. N. G. Dzhanaeva, V. N. Archangelsky note that databases on fertility in a number of former Soviet republics (Latvia, Moldova, Estonia) provide a broader combination of birth characteristics than Rosstat databases [7, p. 370]. I. E. Kalabikhina., D. N. Mokrinsky point to the problem of insufficient operational municipal data on labor resources indicators that has existed for decades [8, p. 101]. Researchers of labor immigration to Russia write about a significant gap between official data on labor migrants and their actual number [9, p. 4]. However, it should be noted that the problem of underreporting of official statistics can also be seen abroad. For example, Clifford F. Thies draws the 
attention of economists to the need to increase the use of additional sources of data on the labor market, since statistics related to unemployment produced by the U.S. Department of labor have some signs of not fully reflecting the changes [10, p. 122].

Second, it is the quality of working with information. Since the beginning of 2000-ies about the necessity of significant expansion and deepening of prepregnancy stages of development by definition quantitative, qualitative and structural indicators of employment actively discuss V.V. Kuzmin, S.G. Kuznetsov, N.M. Kulagina, A.D. Popov [11] etc. But, as noted, E.A. Jedinak, I.B. Korolev, I.N. Dolgov, and today "taken from various sources indicators of labor statistics are often not linked and are scattered datasets, which significantly devalues them" [12, p. 374], which requires changes in the systematization of relevant information at the state level.

The second section of information problems related to official statistics on labor resources and the labor market is more important to us, since in recent years there has been a positive trend of expanding it access for researchers to statistical information. In particular, it is now possible to use in addition to the main source of information (the website of the Federal state statistics service of the Russian Federation) data contained in the Central database of statistics of the Federal state statistics service, and data from the Unified interdepartmental information and statistical system of Rosstat. Making adjustments to the procedure for working with population information arrays (even without changing their volume) can improve the quality of the resulting information, and, consequently, the quality of relevant decisions at all levels of government.

\section{METHODOLOGY OF RESEARCH}

This study is based on the methodology developed by Rosstat of the Russian Federation for creating a balance of labor resources.

The balance of labor resources is a tool for predictive and analytical research of the number and structure of labor resources and labor force. It was widely used in the planned economy of the USSR for intersectoral distribution of labor [13]. Therefore, it is no accident that Russian researchers consider it as the most detailed and important characteristic of the availability and use of labor resources [14]. The practice of using balance models in the system of estimating and forecasting labor resources also takes place in foreign countries - Cambridge MDMModel in the UK, Interindustry FORecasting Germany (INFORGE) in Germany, MONASH and ORANI models in Austria [15, p. 1144].

The model of the region's labor balance as an economic and mathematical model has a multidimensional character. It can be described as an applied macroeconomic model that expresses the requirements for matching the availability of labor resources and their use, based on a priori information, in which all dependencies are assigned to a single point in time and have a matrix type of record [16].
Using the balance of labor resources, we systematize indicators that reflect the availability of labor resources by sources of formation, and indicators that characterize their distribution by employment categories. Since the number of employed labor resources changes during the year, the balance is based on the average annual data.

In the works of russian authors devoted to the problems of methodology of research of labor resources and employment using the labor balance, as a rule, two vectors of research are clearly traced: on the balance of labor resources of regions and on the balance of labor resources of municipalities of regions. In the first group of studies, the authors focus on either making methodological proposals for the first part of the labor balance - the formation of labor resources, or for its second part - the distribution of labor resources by type of activity $[11 ; 12$; $13 ; 14 ; 16]$. A feature of the second line of research is the introduction of proposals on the methodology for calculating individual indicators of the balance of labor resources of municipalities, since the necessary information is missing or has an enlarged nature [15, p. 1147], [17].

\section{RESULTS OF RESEARCH}

The scientific interest of the authors of this research is related to the estimation of the accuracy of calculating the forecast of the region's labor balance in terms of the number and composition of labor resources.

In the Lipetsk region, the forecast of the labor balance is developed by the Department of labor and employment of the Lipetsk region on the basis of a set of relevant data for the reporting period and two types of forecasts - the forecast population of the Lipetsk region and the forecast of socio- economic development of the Lipetsk region for the long term, the next financial year and the forecast period.

In fact, the current territorial development of the Lipetsk region is carried out on the period up to 2025 and a forecast period up to 2040. In the most complete form of the justification of natural conditions, demographic trends and industrial development potential areas are set out in "Scheme of territorial planning of Lipetsk region" [19]. In the "Scheme..." the prognosis of the population of Lipetsk region as the "most likely" (based on typical patterns of development and demographic trends), "optimistic" (based on the demographic trends at carrying out of stimulating the demographic policy), "statistical" (based on the calculation of the estimated population of the Russian Federation up to 2025 made by the Federal state statistics service).

The calculation of the resource (first) part of the labor force balance includes data on the working population at working age with a separate line of working citizens of other countries at working age and data on the employed population outside of working age with separate lines of employed persons older than working age and employed persons younger than working age (adolescents). Currently, 
the basis of the labor resources of a particular territory continues to be the working-age population. Although, as can be seen from figure 1, the share of this part of the labor force tends to decrease due to the all - Russian trend of population aging: in 2010 , it was $91.8 \%$, in $2018-88.6 \%$.

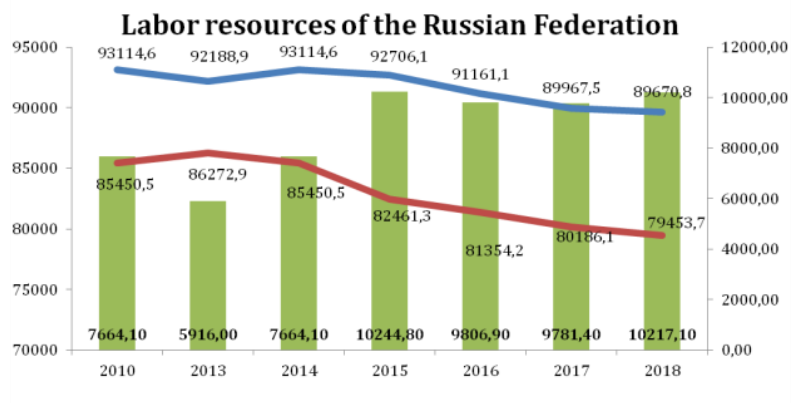

Figure 1 Dynamics of labor resources and working-age population in the Russian Federation in 2010-2018, thousand people [20]

The starting point for calculating the region's labor balance is to consider the demographic forecast as a forecast of the size and structure of the population, since changes in it will entail changes in the population of working age and in the number of labor resources in the region as a whole. The basis of the balance of labor resources in the Lipetsk region is the demographic forecast of the number and composition of the population of the Lipetsk region until 2050 , carried out by employees of the center for the study of population problems of the Moscow State University in 2005 under the leadership of V.N. Arkhangelsky [21].

\section{DISCUSSION OF RESULTS}

Figures 2-5 show the ratio of indicators of the resource part of the labor balance prepared by the Department of labor and employment of the Lipetsk region in the period of the 2010s and early 2020s, and actual data on the number and composition of the labor resources of the Lipetsk region of the Territorial authority of the Federal state statistics service for the Lipetsk region (then Lipstat) for the corresponding years. The information base was the balance of labor resources of the Lipetsk region, calculated for the period 2011-2015, 2012-2016, 20142017, 2019-2021, 2020-2022 [22]. Actual statistics are limited to the period 2011-2018 [23], [24].

Figures 2-5 show that for all categories of labor resources in the region there is a significant discrepancy between the forecast data of the Department of labor and employment in the Lipetsk region and the actual data of Lipstat.

In general, the overall forecast of the region's labor force exceeds the actual indicators of labor resources. The largest deviation corresponds to the period 2015-2017. The maximum gap between forecast and actual data was 37.1 thousand people (2017), the minimum - 5.3 thousand people (2013).

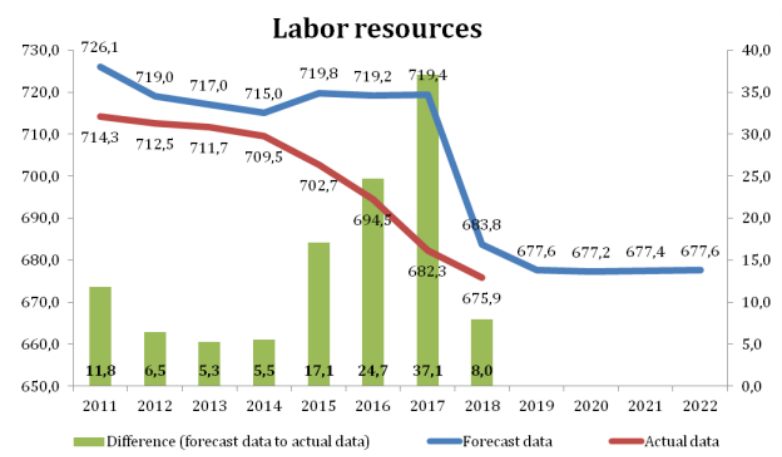

Figure 2 The ratio of indicators of the projected number of labor resources according to the labor balance of the Department of labor and employment of the Lipetsk region and the actual data of Lipstat, 20112018, thousand people

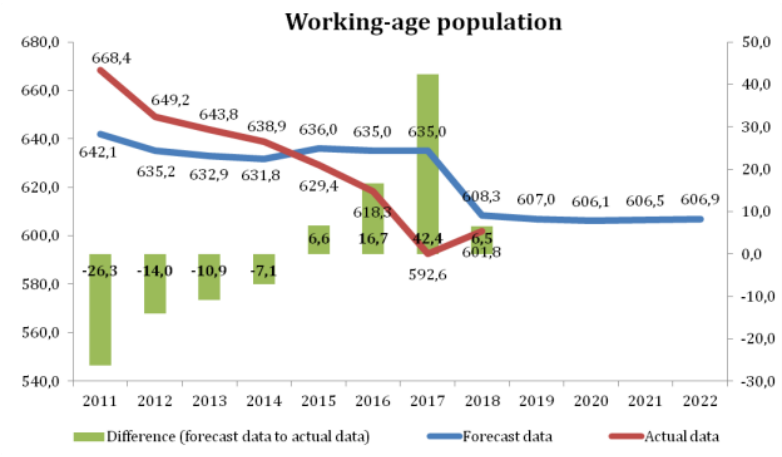

Figure 3 The ratio of indicators of the projected number of working-age population according to the labor balance of the Department of labor and employment of the Lipetsk region and the actual data of Lipstat, 2011-2018, thousand people

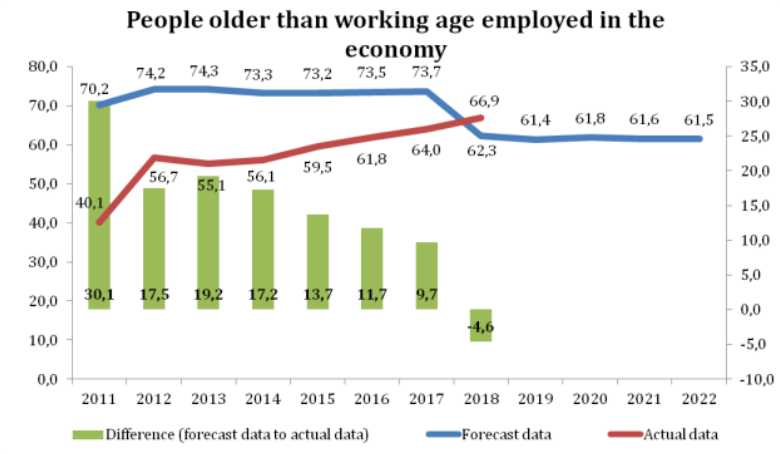

Figure 4 The ratio of indicators of the projected number of people older than working age employed in the economy, according to the balance of labor resources of the Department of labor and employment of the Lipetsk region and the actual data of Lipstat, 2011-2018, thousand people 


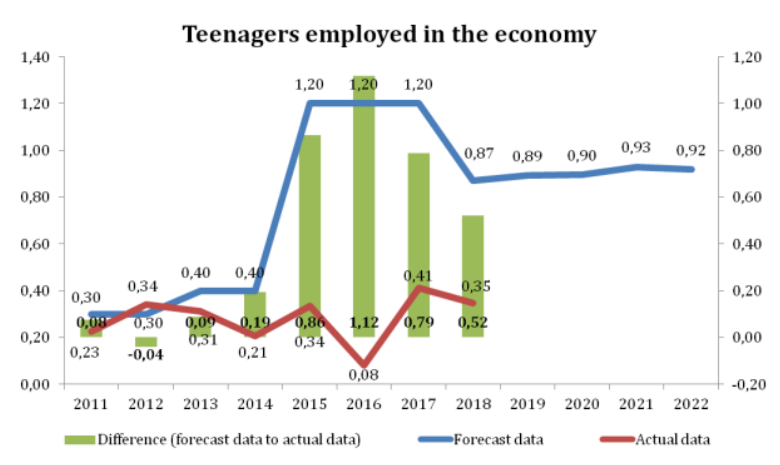

Figure 5 The ratio of indicators of the projected number of teenagers employed in the economy according to the labor balance of the Department of labor and employment of the Lipetsk region and the actual data of Lipstat, 2011-2018, thousand people

The excess of forecast data over actual data is also typical for the number of people employed in the economy who are older than working age and adolescents. At the same time, this gap has been steadily reduced for those employed in the economy who are older than the working age (from 30.1 thousand people in 2011 to 9.7 thousand people in 2017). The forecast data for 2018 were lower than the actual data for this category of labor resources in the Lipetsk region by 4.6 thousand people.

For the forecast data on teenagers employed in the economy, a different dynamic is observed in comparison with the actual data. So, in 2011-2013, the data of this group of labor resources were quite close to each other, but then the forecast data began to significantly exceed the actual data (the maximum gap was 1.12 thousand people in 2016). In 2017-2018, there was a tendency to reduce the gap between forecast and actual data.

At the same time, the forecast data for the number of ablebodied population in working age from 2011 to 2014 were lower than the actual data, but the gap gradually decreased. However, since 2015, the forecast data has exceeded the actual data. The maximum gap was 42.4 thousand people in 2017, and the minimum gap was 6.5 thousand people in 2018.

A significant discrepancy between the forecast and actual data on the number of working-age population is due, in our opinion, to the features of the basic demographic forecast (up to 2050), which is based on the Department of labor and employment of the Lipetsk region in its calculations. Our study showed that V. N. Arkhangelsky's forecast for the Lipetsk region is highly accurate for the age groups of 30-39 years and 80-89 years, but in general it is more pessimistic than the actual situation ( the largest deviation was 1.1 percentage points) $[25$, p. 170, 172].

The presence of a wide range of hypotheses and data allows us to modify the demographic forecast of V.N. Arkhangelsky. In particular, in order to clarify the dynamics of the number and composition of the population of the Lipetsk region, the authors calculated the population forecast using the age distribution method [26]. The similarity of the results obtained for the average version of the forecast for the period 2000-2018 to the real trend in the population of the Lipetsk region makes it highly likely that the forecast values of the population and the workingage population of the Lipetsk region calculated for the following years (up to 2036) also match. However, in the absence of an interactive portal for public relations in the Department of labor and employment of the Lipetsk region (they operate in the Republic of Karelia, the Republic of Komi, the Oryol region, the Nizhny Novgorod region, etc.), it is impossible to quickly convey this information to the management structures.

The inaccuracy of the forecast of the Department of labor and employment for the number of able-bodied population in working age may also be affected by errors in forecasting the number of disabled people and preferential pensioners. Therefore, in some regions, refined methods are used when making a forecast of the labor balance. For example, the methodology for developing the forecast of the balance of labor resources of the Republic of Komi as independent parts of the forecast includes a table with information about the number of disabled people and preferential pensioners and a verification algorithm for the number of able-bodied population at working age [27].

\section{CONCLUSIONS}

As a leading role in the assessment of the workforce plays a precision of abundance estimates the working population in working age, we believe that the reduction of the gap between the predicted number of this category of labor resources in the forecast balance of labor resources of the Lipetsk region and actual data for 2018, as well as the prediction of the weak volatility of this indicator for the period 2019-2022 years (from 1.3 thousand to 2019 to 0.4 thousand people to 2022) is going in the right direction in the regional administrative structures in the field of labor and employment.

At the same time, the study shows that reducing the discrepancy between forecast and actual indicators of labor resources in the region can promote:

1) expanding access to official information on the population and labor to a wide range of users through the use of digital technologies, including by creating an interactive portal on the website of the Department of labor and employment of the Lipetsk region;

2) introduction of additional information on the number of disabled people and privileged pensioners in the region's workforce balance.

\section{ACKNOWLEDGMENT}

Study was supported by Russian Foundation for 
of Saint Petersburg University. - 2013. - Ser. 5. - Vol. 1. - Pp. $3-14$.

[10] Thies C.F. Slip and Drift in Labor Statistics Since 2007 // Econ Journal Watch. - 2017. - Vol. 14 (1). P. $122-132$.

[11] Kuzmin V. V., Kuznetsov S. G., Kulagina N. M., Popov A.D. Problems of forecasting parameters of employment and labor market // Scientific works: Institute of national economic forecasting of the Russian Academy of Sciences. - 2010. - Vol. 8. - Pp. 703-726.

[12] Edinak E. A., Korolev I. B., Dolgova I. N. Some ways of developing statistical and forecast developments in the field of employment and the labor market // Lomonosov readings - 2018. Section of economic Sciences. Digital economy: people, technologies, institutions: a collection of abstracts. Moscow: faculty of Economics of Lomonosov Moscow state University, 2018. - Pp. 373-376.

[13] M.G. Bobaru, C.S. Pasareanu, D. Giannakopoulou, Automated assume-guarantee reasoning by abstraction refinement, in: A. Gupta, S. Malik (Eds.), Proceedings of the Computer Aided Verification, Springer, Berlin, Heidelberg, 2008, pp. 135-148. DOI: https://doi.org/10.1007/978-3-540-70545-1_14

[14] Korovkin A.G., Dolgova I.N., Edinak E.A., Korolev I.B. Experience of macroeconomic analysis and forecasting of employment and labor market in the Russian economy // Management. - 2015. - Volume 3. No. 1. - Pp. 43-54

[15] Pencheva S.N. Balance of labor resources : theoretical aspect // Bulletin of the Altai State Agrarian University. - 2012. - No. 11 (97). - Pp. 95-99.

[16] Balkhanov A.M. Application of the balance of labor resources in forecasting the labor market in the region // Decent work - the basis of a stable society: proceedings of the IV international scientific and practical conference: in 2 volumes. - Yekaterinburg, 2014. - Pp. 3-9.

[17] Yusupova I.V., Titova A.V. Tools for studying the territorial mobility of the population and forecasting the state of labor resources of municipalities of the Republic of Tatarstan // Kazan economic Bulletin. 2018. - No. 4 (36). - Pp. 40-44.

[18] Approval of the Methodology for calculating the balance of labor resources and estimating labor costs. problems and new approaches to regulation // Vestnik 
Rosstat order No. 647 of September 29, 2017. - Access mode: http://docs.cntd.ru/document/456096329.

[19] About the approval of the scheme of territorial planning of the Lipetsk region (with changes for October 1, 2018). Resolution of the Lipetsk region administration No. 130 of June 5, 2008 (as amended by resolution of the Lipetsk region administration No. 373 of 30.07.2015, No. 461 of09.10.2017, and No. 529 of 01.102018). - - Access mode: http://docs.cntd.ru/document/872609621

[20] Labour and employment in Russia - 2019 Average annual number and structure of labor resources. Access mode: https://gks.ru/bgd/regl/b19_36/Main.htm.

[21] Arkhangelsky V.N. Forecast of the number and composition of the population of the Lipetsk region until 2050 / / Demographic Bulletin. Lipetsk. - 2005. No. 2. - Pp. 23-49.

[22] The balance of labor resources in the Lipetsk region. - Access mode: http://utiz.lipetsk.ru/files/balans-svod1.pdf; http://utiz48.ru/wpcontent/uploads/2019/09/prognoz_trud.pdf.

[23] Labor resources of the Lipetsk region. 2014: Stat. sat. / Lipeckstat. - L., 2015. - 39 p.

[24] Labor resources of the Lipetsk region. 2019: Stat. sat. / Lipeckstat. - L., 2019. - 30 p.

[25] Novak M.A., Kozlova E.I. Retrospective and perspective analysis of the demographic situation in the Lipetsk region // Bulletin of the Belgorod University of cooperation, economics and law. - 2019. - No. 1. - Pp. 166-181.

[26] Novak M. A., Kozlova E. I. Application of the Method of Moving Ages to Predict the Population of the Lipetsk Region // 2019 1st International Conference on Control Systems, Mathematical Modeling, Automation and Energy Efficiency (SUMMA). Lipetsk, Russia, 2019, pp. 224-228.

[27] Yusupova I. V. Balance model of labor resources of the Komi Republic // Society: politics, economics, law. - 2015. - No. 1. - Pp. 40-44. 